\author{
Mirosław SOLTYSIAK ${ }^{1}$ \\ Dariusz ZAJĄ $\mathbf{C}^{2}$
}

\title{
THE DIVERSITY OF MATERIAL LIVING CONDITIONS FOR RESIDENTS FROM EASTERN AND WESTERN REGIONS OF POLAND
}

\begin{abstract}
The article assesses the material living conditions of the population in the eastern and western regions of Poland against the background of the country and its changes in 2010-2018 . The spatial scope of the research covers the entire country, including the eastern and western regions of Poland, i.e., territorial government units (voivodships) where the administrative border is also the state border. The temporal scope of the research covers the years 2010 and 2018. The empirical material of the article consists of data from the Central Statistical Office in Warsaw, especially the Household Budget Survey. The empirical material was developed in a graphic form using the method of comparative analysis and a scoring method for all diagnostic features illustrating the material living conditions of residents in the studied regions of Poland against the background of the country in 2010-2018. The conducted analysis showed that there are regional disproportions in terms of the material living conditions of the inhabitants. Even though most of the studied regions improved in this regard over the period studied, the eastern regions of Poland are still falling short in comparison to the western regions. In addition, there are also discrepancies in this respect between individual eastern and western regions. The material living conditions of the inhabitants in most of the analyzed Polish regions should be treated, among other things, as the result of the implementation of the European Union cohesion policy, especially in the eastern regions, which are classified as the least economically developed in the EU.
\end{abstract}

Keywords: Material living conditions, eastern and western regions of Poland.

\section{INTRODUCTION}

The goal and sense of socio-economic development is primarily to improve the quality and living conditions of residents, i.e. social welfare (Woźniak, 2018). One of the priorities of the European Union's cohesion policy is development support that should lead to the reduction of development disparities between the Member States, their regions and local environments. On the other hand, its effect is to increase the competitiveness of the regional and local economy and improve the quality and living conditions of the inhabitants. In this context, the territorial approach, understood as geographical space along with its

\footnotetext{
${ }^{1}$ Mirosław Sołtysiak, PhD, Eng., Rzeszow University of Technology, The Faculty of Management; e-mail: miroslaw@prz.edu.pl. ORCID: 0000-0003-3366-1537 (corresponding author).

2 Dariusz Zając, PhD, DSc, Eng., prof. UR, Institute of Economics and Finance, University of Rzeszow; e-mail: dzajac@ur.edu.pl. ORCID: 0000-0001-7918-1366.
} 
inhabitants, in the process of improving cohesion is more and more emphasized (Polverari, Bachtler, 2005; Lambregts, Janssen-Jansen, Haran, 2008; Czudec, Majka, Zając, 2018; Miś, Zając, 2020).

The quality of life in the evaluative aspect is reflected in the objective and subjective assessment. The standard and living conditions make up the objective quality of life, while the subjective quality of life is the perception of an individual's psychological state, expressed by satisfaction, content and happiness (Kędzior, 2003). Objective quality of life is similar to the concept of living conditions, which include: household income, expenditure on food, nutrition quality, housing conditions, household equipment, including access to modern communication technologies (mobile phone, computer, Internet), the scale of using social assistance, children's education, the use of various forms of health protection, various aspects of social exclusion (unemployment, disability, poverty), participation in cultural life, forms of recreation etc. (Czapiński, Panek, 2009; Sompolska-Rzechuła, 2013).

The quality and living conditions of the population are shaped by many different factors. Some of them are a derivative of economic development processes and therefore are determined by the market mechanism, while others are determined by the institutional sphere of the public sector. The first group includes factors related to the labour market (unemployment, employment and working conditions, job satisfaction), the level of income earned, and the structure of expenses (food, other consumer goods, including housing expenses). On the other hand, the second group of factors includes the availability and degree of residents' satisfaction with health care, education, transport networks and cultural institutions. These are factors influenced mainly by local government units, as well as by state institutions. The same group of factors also includes the condition of the natural environment, which - due to the imperfection of the market in this sphere - directly depends on the activity of public sector institutions and affects not only the quality of life of residents, but also visitors, vacationing in places offering tourist attractions. The quality and living conditions of the population are thus influenced by many different instruments of economic policy. The most important ones can be divided into three groups, i.e. stimulating economic development at the regional level and thus influencing the situation on the labour market and the level of household income, supporting the development of technical and social infrastructure facilitating the residents' access to health care and education, culture, recreation, as well as improving the transport accessibility of regions and the condition of the natural environment (Błachut, Cierpiał-Wolan, Czudec, Ślusarz, 2017).

The results of research on the quality and living conditions of the population are very important in the decision-making process regarding strategic directions of socio-economic development. This is of importance at the regional level, because a low level of quality and living conditions and the lack of real prospects for their improvement most often result in migration to those regions which, in the opinion of migrants, are better. A consequence of the long-term migration process is weakening of the socio-economic development opportunities of depopulating regions, which in subsequent years lead to intensification of negative migration trends and deepening of interregional disproportions (Błachut, CierpiałWolan, Czudec, Ślusarz, 2017). It should be noted that, compared to other European Union countries, not only the regions in eastern Poland, but also other regions have a long distance to cover when it comes to levelling the differences in terms of the quality of living conditions, and there are not only the so-called "Old" Union regions, but also most of the new members of the EU (Balcerzak, Pietrzak, 2015; Wawrzyniak, 2016). The research shows that there are clear differences between individual European Union countries in terms 
of the quality of living conditions, with Scandinavia and Luxembourg among the countries at the top of the list. These countries have a low level of material deprivation and the highest level of overall life satisfaction. The bottom line, well below the European Union average, are regions found in countries such as Romania, Bulgaria and Latvia. On the other hand, Poland is in the group of countries where the quality of living conditions is rated lower than the European Union average (Raczkowska, 2016).

Due to the fact that the quality of living conditions is characterised with a wide range of meaning and referring to various spheres of human activity, a properly conducted assessment should not be limited only to the analysis of individual components, but also requires contrasting with the quality of living conditions in earlier years (change index) and with other regions (regional level index) (Błachut, Cierpiał-Wolan, Czudec, Ślusarz, 2017).

\section{PURPOSE, SCOPE, EMPIRICAL MATERIAL AND RESEARCH METHODS}

The aim of the article is to assess the material living conditions of the population in the eastern and western regions of Poland contrasted with the entire country and the changes arising in 2010-2018.

The spatial scope of the research covers both the entire country and the eastern regions of Poland, i.e. the Podlaskie, Lubelskie and Podkarpackie voivodeships, and the western regions of Poland, i.e. the Zachodniopomorskie, Lubuskie and Dolnośląskie voivodeships, i.e. the regions where the administrative border is also the state border. The time scope of the research, in turn, covers the years 2010 and 2018.

The empirical material of the article consists of data from the Central Statistical Office in Warsaw - Household Budget Survey. The collected and structured empirical material was developed graphically, using the method of comparative analysis, with comparisons made in time and space.

For the purpose of the study, 32 diagnostic features were used that characterize the material living conditions (i.e. income, expenses and food consumption) of the inhabitants of the entire country as well as the eastern and western regions of Poland, as well as the transformations in 2010-2018. The features include:

1. average monthly net income per capita in households (PLN);

2. average monthly disposable income per capita in households (PLN);

3. average monthly income per capita in households (PLN);

4. average monthly income from contract work per capita in households (PLN);

5. average monthly income from self-employment per capita in households (PLN);

6. average monthly social insurance benefits per capita in households (PLN);

7. average monthly net expenses per capita in households (PLN);

8. average total monthly expenditure per capita in households (PLN);

9. average monthly expenditures on consumer goods and services per capita in households (PLN);

10. average monthly expenditure on food per capita in households (PLN);

11. average monthly expenditure on clothing per capita in households (PLN);

12. average monthly expenditure on the use of a flat and energy carriers per capita in households (PLN);

13. average monthly expenditure on health per capita in households (PLN);

14. average monthly expenditure on transport per capita in households (PLN);

15. average monthly expenditure on communication per capita in households (PLN); 
16. average monthly expenditure on education per capita in households (PLN);

17. average monthly expenditure on recreation and culture per capita in households (PLN);

18. average monthly expenditure on restaurants and hotels per capita in households (PLN);

19. average monthly expenditures on other goods and services per capita in households (PLN);

20. average monthly consumption of bread and cereal products per capita in households $(\mathrm{kg})$;

21. average monthly meat consumption per capita in households $(\mathrm{kg})$;

22. average monthly consumption of cold cuts per capita in households $(\mathrm{kg})$;

23. average monthly consumption of fish and seafood per capita in households $(\mathrm{kg})$;

24. average monthly consumption of milk per capita in households (litre);

25 . average monthly consumption of yoghurt per capita in households $(\mathrm{kg})$;

26. average monthly consumption of cheese and cottage cheese per capita in households $(\mathrm{kg})$;

27. average monthly fruit consumption per capita in households $(\mathrm{kg})$;

28. average monthly consumption of vegetables per capita in households $(\mathrm{kg})$;

29. average monthly consumption of sugar and confectionery products per capita in households $(\mathrm{kg})$;

30. average monthly consumption of coffee, tea and cocoa per capita in households $(\mathrm{kg})$;

31. average monthly consumption of mineral and spring waters per capita in households (litre);

32. average monthly consumption of fruit and vegetable juices per capita in households (litre).

The study included a point assessment of all diagnostic features illustrating the material living conditions of residents in the eastern and western regions of Poland set against the background of the entire country in 2010 and 2018. Individual diagnostic features were compared with the national average, which was assumed to be 100 points, and their advantage or underweight was assessed accordingly in the studied regions. Then all points were summed up and the mean was calculated.

\section{RESULTS}

When assessing all the analysed diagnostic features characterizing household income as a component of the material living conditions, it should be noted that there are significant disproportions in Poland in this respect. Eastern regions of Poland as compared to the western ones are in a much worse situation. Western area is clearly doing better, being close to the national average. In addition, there is also a discrepancy in terms of household income between individual eastern and western regions. Because as the eastern regions are concerned, Podkarpackie Voivodeship is in the worst situation, as opposed to Podlaskie Voivodeship which situation is by far better. On the other hand, in the West of the country, the best situation is seen in Dolnośląskie and Zachodniopomorskie voivodeships, and the worst in Lubuskie (Fig. 1).

In addition, it should be noted that in 2010-2018, with the exception of the Dolnośląskie Voivodeship (where the income situation of households slightly deteriorated, but still being 
above the national average), all other regions of Poland under research improved in terms of household income which constitutes a component of the inhabitants' material living conditions Despite this, however, Eastern regions of Poland as compared to the western ones are in a much worse situation. Western area is clearly doing better, being close to the national average. In addition, still there are still differences in terms of household income between individual eastern and western regions. In the case of eastern regions of Poland, the Podkarpackie Voivodeship is in the worst situation, and the Podlaskie Voivodeship being the exact opposite. On the other hand, in the case of western regions, the best situation is in the Zachodniopomorskie and Dolnośląskie voivodships, and the worst in the Lubuskie voivodship, where it is closest to the average for the whole country (Fig. 1).

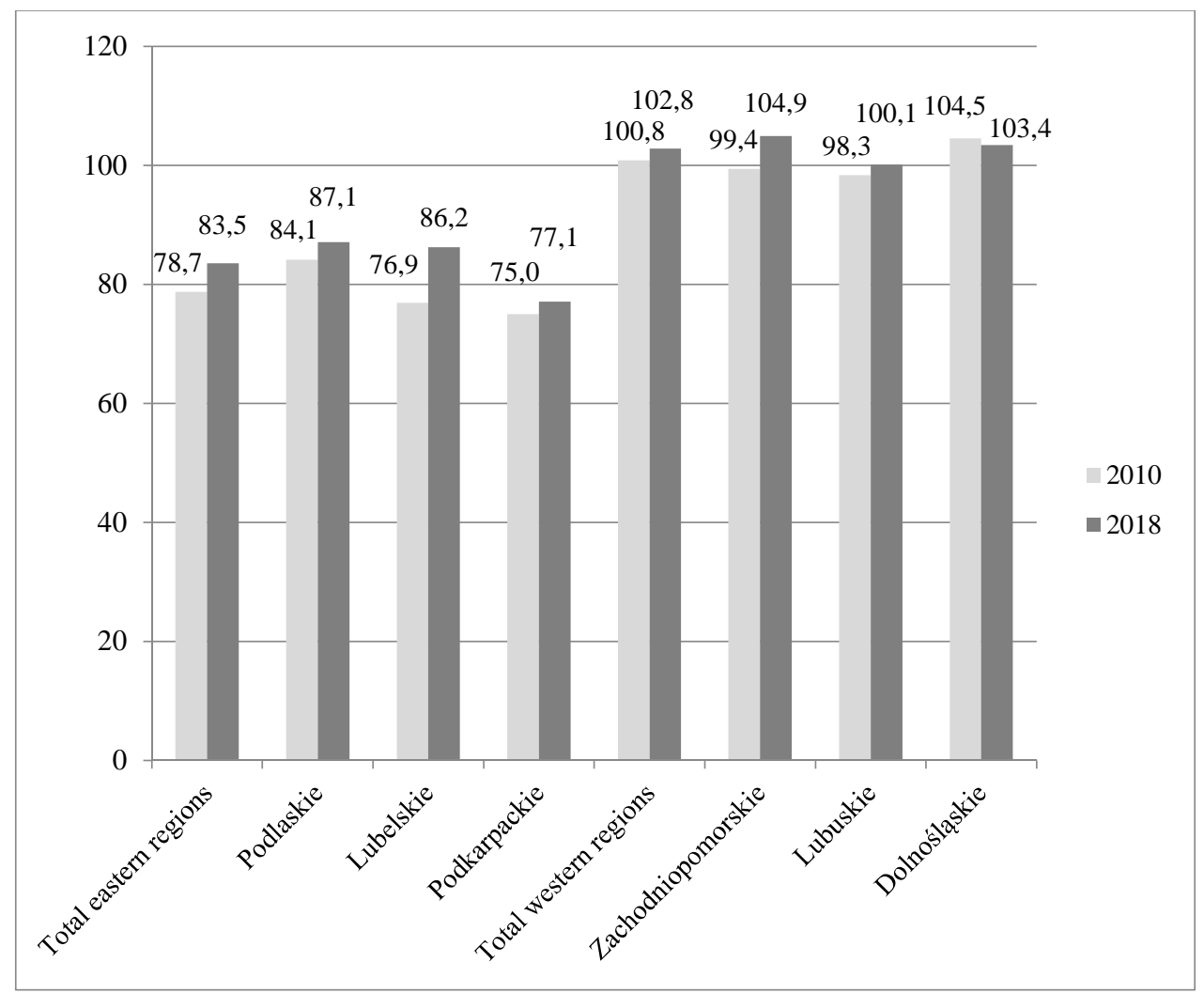

Fig. 1. Point assessment of all diagnostic features characterizing household income as a component of the material living conditions of residents in the researched regions at the background of the entire country in 2010 and 2018 (Poland $=100.0$ points)

Source: original study based on data from Central Statistical Office in Warsaw.

When assessing all the analysed diagnostic features characterizing household expenses as a component of the material living conditions of the inhabitants, it should be stated that, as in the case of income, there are large regional disproportions in this respect in Poland. The eastern regions of Poland are characterized by a clearly worse situation in this respect, 
compared to the western regions, where the situation is much better and close to the national average. Moreover, there are also discrepancies in this respect between the individual eastern and western regions. In the case of eastern regions of Poland, the Podkarpackie is in the worst situation, and in the West, Lubuskie. On the other hand, the best situation in this respect is in the Dolnośląskie Voivodeship, clearly above the average for the entire country (Fig. 2).

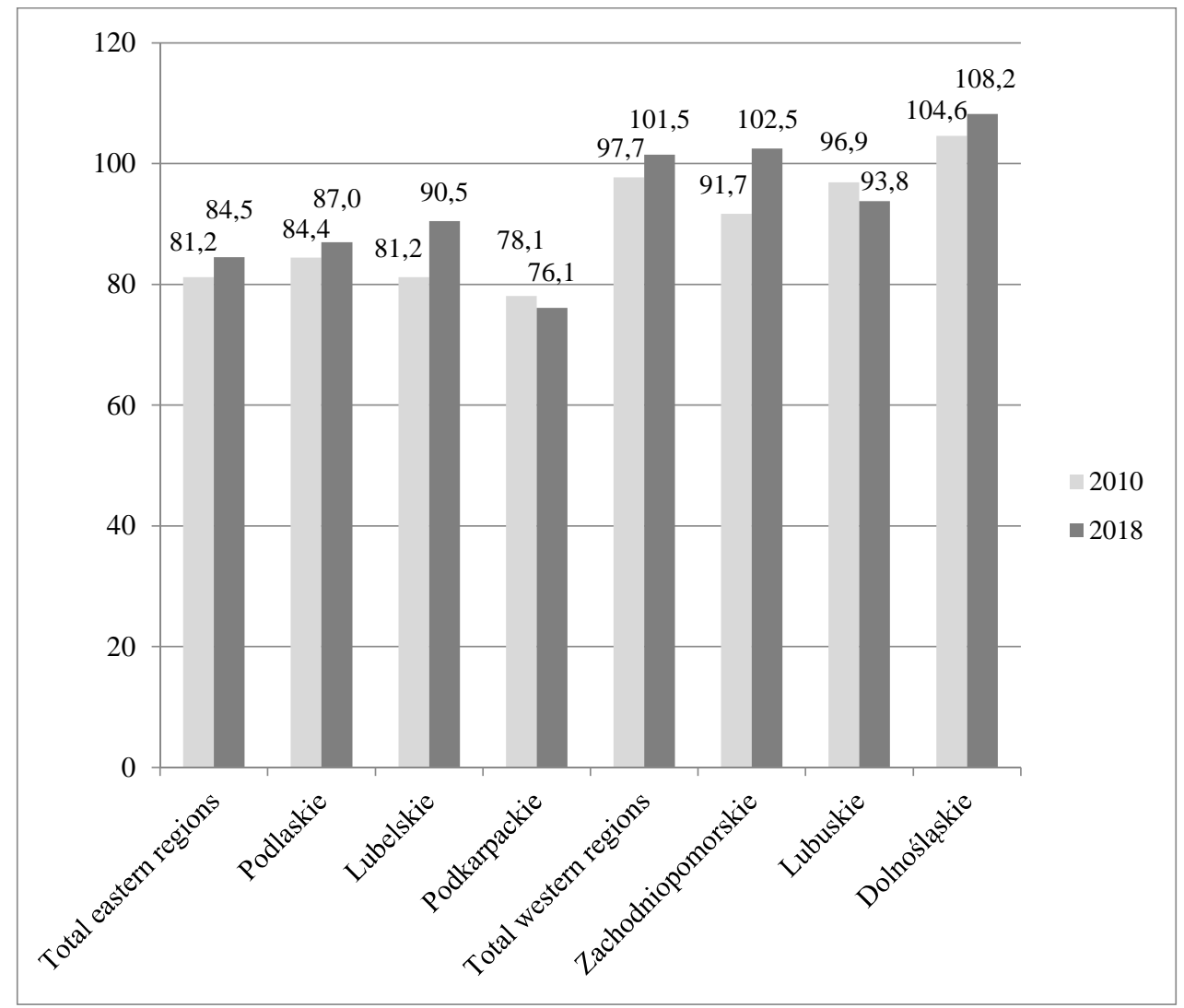

Fig. 2. Point assessment of all diagnostic features characterizing household expenditure as a component of the material living conditions of inhabitants in the researched regions covered by the research at the background of the entire country in 2010 and 2018 (Poland $=100.0$ points)

Source: original study based on data from Central Statistical Office in Warsaw.

It should be added that in 2010-2018, except for the Podkarpackie and Lubuskie voivodeships, all other researched regions of Poland improved in terms of household expenditure as a component of the residents' material living conditions, especially in the Lubelskie and Zachodniopomorskie voivodeships. Despite this, however, the eastern regions of Poland are still characterized by a much worse situation in this respect, compared to the western regions, where the situation is clearly better and close to the country's 
average. Moreover, there are also differences in this respect between individual regions in the East and the West. Within eastern regions, Podkarpackie Voivodeship is still in the worst situation, and in the case of western regions, Lubuskie. Those are the areas where the situation in terms of household expenditure as a component of material living conditions worsened in 2010-2018 (Fig. 2).

When assessing all the analysed diagnostic features characterizing the consumption of foodstuffs in households as a component of the residents' material living conditions, it should be noted that in Poland there are no major differences in this respect between the eastern and western regions, where the situation in this respect is similar to the country's average Additionally, there are no major differences in the household consumption of foodstuffs as a component of the residents' material living conditions between individual eastern and western regions. It should be added that in this respect Podlaskie voivodship is in the best situation out of Polish eastern regions, and in the case of western regions, Zachodniopomorskie Voivodeship (Fig. 3).

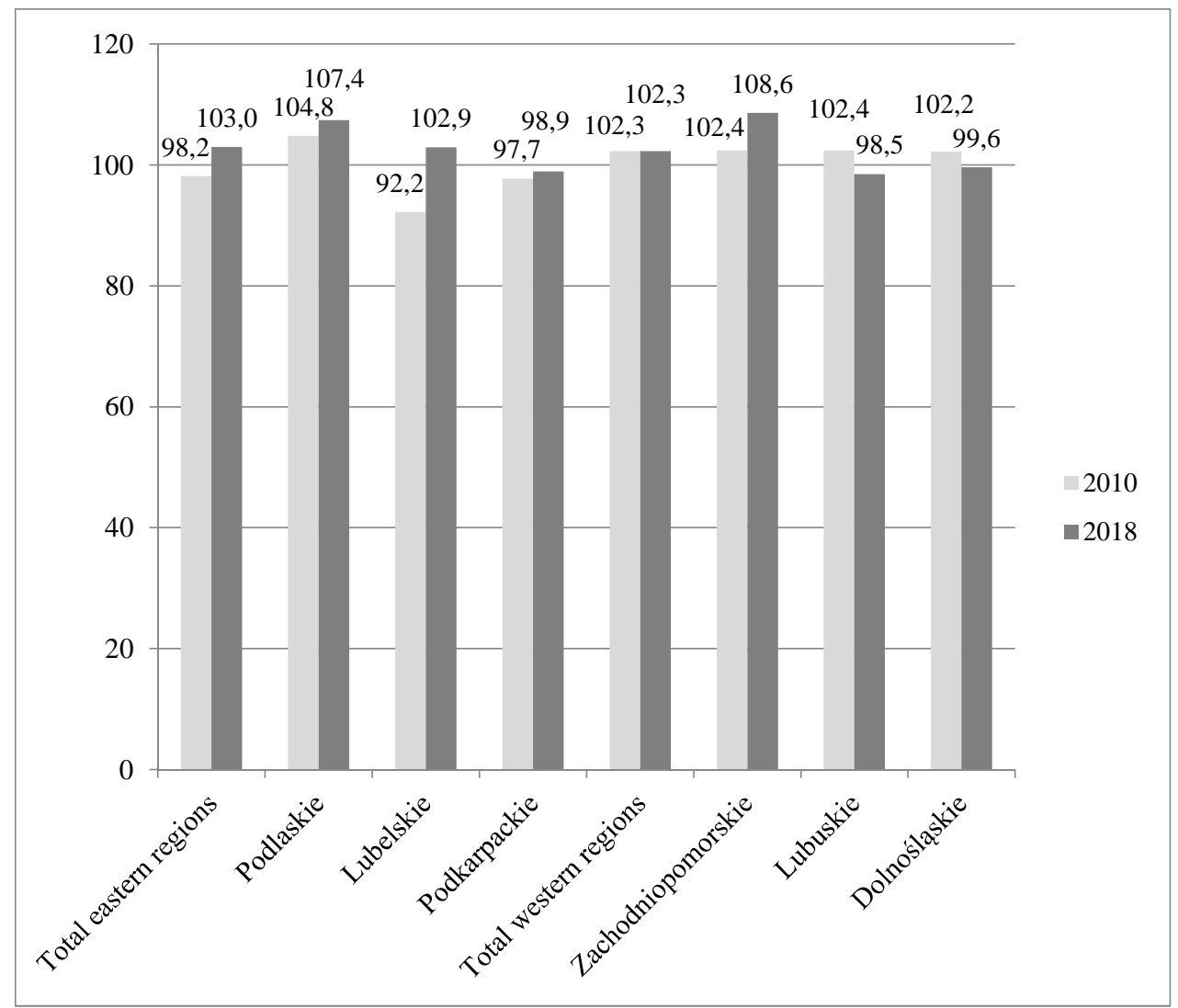

Fig. 3. Point assessment of all diagnostic features characterizing household foodstuffs consumption as a component of the material living conditions of residents in the researched at the background of the country in 2010 and 2018 (Poland $=100.0$ points)

Source: original study based on data from Central Statistical Office in Warsaw. 
Moreover, in 2010-2018, except for Lubuskie and Dolnośląskie, in all other researched regions of Poland, there was an improvement in the household food consumption $d$ as a component of the material living conditions. It should be added that this applies especially to the Lubelskie and Zachodniopomorskie Voivodeships, and to the least extent to the Podkarpackie Voivodship. However, even though the situation in the Lubuskie and Dolnośląskie Voivodeships in 2010-2018, worsened in this respect, it is still similar to the national average (Fig. 3).

When assessing all the analysed diagnostic features characterizing the material living conditions of inhabitants in the studied areas, it should be stated that in Poland there are disproportions in this respect between regions of the East and the West. The eastern regions of Poland are characterized by a worse situation in comparison to the western regions, where the situation is better and like the national average. Moreover, there particular areas differ in terms of residents' material living conditions within eastern and western regions. Out of the eastern regions of Poland, Podkarpackie region is in the worst situation, and in the case of western regions it is Lubuskie voivodship (Fig. 4).

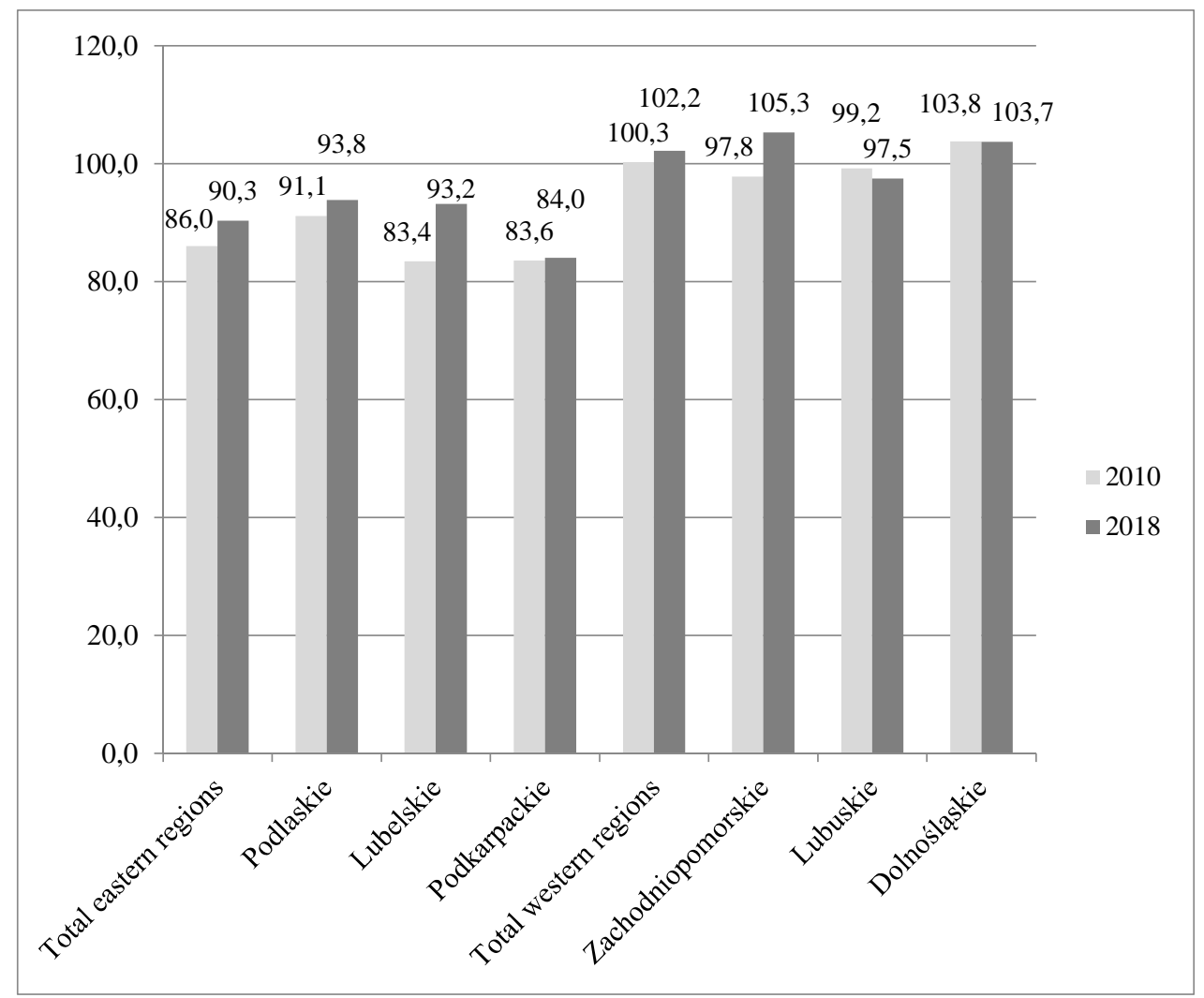

Fig. 4. Point assessment of all diagnostic features characterizing the material living conditions of inhabitants in the researched regions compared to the entire country in 2010 and 2018 (Poland $=100.0$ points)

Source: original study based on data from Central Statistical Office in Warsaw. 
In addition, it should be noted that in 2010-2018, apart from the Lubuskie and Dolnośląskie voivodeships, all other studied regions of Poland improved in terms of material living conditions. It is mainly visible in the Lubelskie and Zachodniopomorskie voivodeships, and to the least extent in the Podkarpackie Voivodeship. Despite this, however, the eastern regions of Poland, as compared to the West, are still in a worse situation in this respect, The West is doing better, with a similar average to national. In addition, individual regions within the East and the West vary in terms of the material living conditions of their inhabitants. In the case of the eastern regions of Poland, the Podkarpackie Voivodeship is still in the worst situation, and in the case of western regions, it is the Lubuskie Voivodeship. However, even though the situation in the Lubuskie and Dolnośląskie Voivodeships, slightly worsened in 2010-2018, it is still like the national average, with Dolnośląskie Voivodship with the advantage (Fig. 4).

\section{CONCLUSIONS}

1. In Poland, there are significant regional disproportions in terms of household income and expenditure as components of the material living condition. Despite the fact that in 2010-2018, most of the studied regions improved in this respect, the eastern regions of Poland are still characterized by a much worse situation, compared to the western regions, where the situation is clearly better and similar to the national average. In addition, there are also discrepancies in this respect between individual eastern and western regions. Poland has a large regional differentiation in terms of the material living conditions of its inhabitants.

2. In Poland, there are no major regional differences in terms of the consumption of household food as a component of the material living conditions of the inhabitants. In addition, in the years 2010-2018, most of the studied regions improved in this respect, especially the Lubelskie and Zachodniopomorskie voivodeships. However, even though in the Lubuskie and Dolnośląskie Voivodeships the situation has worsened, it is still like national average.

3. In Poland, there are regional disproportions in terms of the residents' material living conditions. Even though in 2010-2018 most of the studied regions improved in this regard, the eastern regions of Poland are still characterized by a worse situation compared to the western regions, where the situation is better and like national average. Moreover, individual regions in the East and the West vary in this respect.

4. The improvement of the material living conditions in the majority of the studied eastern and western regions of Poland in 2010-2018 should be treated, inter alia, as a result of the implementation of the European Union's cohesion policy, especially in the eastern regions, which are classified as the least economically developed in the EU.

\section{REFERENCES}

Balcerzak, A. P., Pietrzak, M. B. (2015). Wptyw efektywności instytucji na jakość życia w Unii Europejskiej. Badanie panelowe dla lat 2004-2010. „Przegląd Statystyczny”, R. LXII, z. 1 .

Błachut, B., Cierpiał-Wolan, M., Czudec, A., Ślusarz, G. (2017). Jakość życia w województwie podkarpackim w latach 2004-2015. Rzeszów: Urząd Statystyczny w Rzeszowie, Uniwersytet Rzeszowski. 
Czapiński, J., Panek, T. (2009). Diagnoza społeczna. Warunki i jakość życia Polaków. Warszawa: Wyższa Szkoła Finansów i Zarządzania.

Czudec, A., Majka, A., Zając, D. (2018). Impact of European Union Cohesion Policy at Local Level (Rural Areas of Eastern Poland Case Study). "Lex localis - Journal of Local Self-Government" No. 4, Vol. 16.

Kędzior, Z. (2003). Metodologiczne aspekty badania jakości życia [In:] Karwowski, J., ed., Jakość życia w regionie. Szczecin: Uniwersytet Szczeciński.

Lambregts, B., Janssen-Jansen, L., Haran, N. (2008). Effective governance for competitive region in Europe: the difficult case of the Randstad. "GeoJournal” No. 72.

Miś, T., Zając, D. (2020). Results of European Union Cohesion Policy in Terms of Quality of Life Improvement on a Regional Level (as Exemplified by Eastern Poland). "Lex localis Journal of Local Self-Government” No. 1, Vol. 18. DOI: 10.4335/18.1.53-69(2020).

Polverari, L., Bachtler, J. (2005). The contribution of European Structural Funds to territorial cohesion. "Town Planning Review” No. 76 (1).

Raczkowska, M. (2016). Jakość życia w krajach Unii Europejskiej. „Prace Naukowe Uniwersytetu Ekonomicznego we Wrocławiu, Ekonomia” nr 449.

Sompolska-Rzechuła, A. (2013). Jakość życia jako kategoria ekonomiczna. „Folia Pomeranae Universitatis Technologiae Stetinesis, Oeconomica” No. 301(71).

Wawrzyniak, D. (2016). Standard Of Living In The European Union. “Comparative Economic Research" No. 1, Vol. 19.

Woźniak, M. G. (2018). Nowa ekonomia strukturalna w kontekście rozwoju zintegrowanego. „Nierówności Społeczne a Wzrost Gospodarczy”, z. 54(2/2018). DOI: 10.15584/nsawg. 2018.2.3.

DOI: $10.7862 /$ rz.2021.hss.08

The text was submitted to the editorial office: December 2020

The text was accepted for publication: March 2021 